\title{
Development of Authentic Assessment Learning Model In Achieving Skill of Literary Text: A Strategy for Establishment of Young Generation Character
}

\author{
Nurizzati, Ena Noveria, Ermawati Arief \\ Fakultas Bahasa dan Seni \\ Universitas Negeri Padang
}

\begin{abstract}
Lessons learned and evaluation Literary Appreciation tend to be neglected: less procedural, less precise, and less effective. Measuring appraisal tools of literary appreciation are mostly only up to the level of knowledge (cognitive), not to measure the psychomotor and affective aspects. Therefore, the purpose of this study was to develop an authentic assessment model to measure the achievement of KD learning ability to appreciate literary texts in the Curriculum 2013 at high school level as a strategy to form the noble character of the nation's youth. Assessment development of the ability to appreciate this literary text needs to be done by first doing needs analysis, KD analysis, material analysis, and student analysis. The design of the implications of developing an authentic assessment model of learning the ability to appreciate literary texts is guided by KD learning to appreciate literary texts (short stories) and its training stages include understanding, producing, and comparing text. In addition, it is also guided by the training of language aspects in the Curriculum 2013.
\end{abstract}

Keywords--ability to appreciate, short story text, development of authentic assessment model, authentic assessment instrument

\section{INTRODUCTION}

Assessment is the third main task of the teacher. This task is carried out by teachers based on an assessment that should have been prepared in conjunction with RPP and a series with the materials used and developed in the learning psoses. Even if the teacher applies the concept of authentic assessment, during the learning process the teacher conducts the assessment because the psychomotor and affective spheres are assessed in the learning process. This activity clearly requires teachers to prepare assessments, especially standard process measuring tools for determining student achievement levels in learning consisting of a grid of test materials, questions or tests, scoring guidelines, and answer keys (Djiwandono, 2011, p. 202). The 2013 curriculum means assessment is the process of documenting knowledge, skills, attitudes, and beliefs structurally (Atmazaki, 2013, p. 16).

The development of authentic assessment models and tools of learning the ability to appreciate literary texts in which case short stories need to be in effective literary appreciation learning in the classroom. Referring to the opinion of some experts that in language and literature learning, students are given the opportunity to display language skills, such as speaking, reading, and writing various forms of essay (Schulz, 2009; Atac, 2012; Shahrakipour, 2013; Mahmoud, 2013); students are prepared and given the opportunity to practice appreciation of literary works in the classroom, from understanding, then producing, then comparing in accordance with the stages of learning text-based Indonesian language (Mahsun, 2014).

Conceptually, the types of authentic assessments developed for learning to appreciate short story texts can bring a fun, challenging learning environment, and increase the spirit of learning and students' ability to appreciate literary works, even producing literary works. Teachers and students build knowledge, give meaning, seek clarity, be critical, communicate, and be able to justify in the learning process. Learning becomes a process that helps students to think correctly, because the instruments given to students train and give their own opportunities to think. Students can think well is more important than having the right answer. A person who has a good way of thinking can use this way of thinking in the face of a new phenomenon and can find solutions in the face of other problems. According to Albrecht (1992) for an individual to arrive at a logical level of thinking, the individual must understand the logical proposition consisting of three parts and showing progressive ideas, i.e., the basic thought or reality of footing, argumentation or placing the rationale together, and the conclusions or results which is achieved by applying argumentation on the basis of thought. 


\section{METHODS}

Theoretically, authentic assessment can increase student activity and spirit of learning. In accordance with the scientific approach, students appear active to observe, question, discover, collect information and build their own knowledge. The student makes a reasoning about the problem he or she is studying by finding meaning, and comparing it with what he already knows and resolving the inequalities between what is known and what is required in the new experience (Channa and Nordin, 2015). Students are responsible for the learning outcomes, each of them has his own way of constructing his knowledge which is sometimes very different from his friends. Teachers contribute to creating a variety of learning situations and methods while utilizing assessment tools as a learning tool. Based on the concept of literature appreciation learning synchronized with the learning of literary ability, the models and tools developed achieve a high level of appreciation, even creative appreciation.

\section{FINDING AND DISCUSSION}

The learning appraisal system implemented at all levels of educational units in Indonesia has been oriented towards a final assessment or assessment of learning that leads to quantitative value. Assessment process has not received attention and proportional handling of teachers or implementers of learning. One assessment of the sub-field of learning that has not received attention seriously and adequately, has not been adequately balanced and has not used the appropriate measuring tool in the National Exam, also on the National Examination exam, maybe even the assessment of school level results is the assessment of literary learning outcomes that become an integral part of the Indonesian language course. Assessment model or form of question for Indonesian language and literature test to measure the achievement of the learning result of language and literature is not proportional, either form or number of questions. Even if there are items that test the literary material, the status is more on the mastery of cognitive aspects in line with the assessment of language aspects (aspects of reading and writing for the grid about the 2009 UN). Whereas the achievement of every KD in the Curriculum must be measured proportionally. Literary materials filled with human values, morals, and life are only tested as knowledge (cognitive). Measurements of skills aspects (psychomotor) and attitudes (affective) have not been implemented in a balanced manner.

The development of authentic instruments in the ability to read short-story text reaches a high level of appreciation; and the development of an instrument of writing skills based on a readable short story text achieving creative appreciation. Both are high levels of appreciation. In addition, in accordance with the skill aspects to be trained in Indonesian Language and Literature, an authentic assessment model developed for training, listening, speaking, reading, writing, studying, and viewing tools.

\section{Authentic Assessment Tool Learning Capabilities Appreciating Short Story Text to Achieve Literature Appreciation Level}

Instrument tool of each type of authentic assessment instrument learning ability to appreciate text of the short story guides students to train appreciation ranging from low appreciation, moderate, to high appreciation. The instrument of authentic assessment instrument of learning ability to appreciate the text of the short story indicating low appreciation is the assessment of retelling the contents of the story. In this activity the students just retell the contents of the story in accordance with the content that is understood by them after reading the story. The measurement indicators are: (1) the ability of the students to retell the short story clearly, (2) in accordance with the contents of the story, (3) complete, and (4) in good (effective) language.

Appreciation is being done when students are able to identify the elements of the short story text they are reading, or display the readings with intimate appreciation, rhythmic vocals (sounds), and appearances that support appreciation and vowel. Identifying the elements of short story text that the students have read is a medium appreciation with an indicator of students' ability to: (1) construct a synopsis and identify the appropriate flow, setting, character, and theme; (2) constructing synopsis and identifying the flow, background, actors / characters, and written themes completely; (3) construct a synopsis and identify paths, backgrounds, actors / characters, and themes according to the story being read; (4) using the language appropriately and effectively in constructing synopsis and identifying the flow, the background, the perpetrators / characters, and the themes.

The instrument of authentic assessment instrument of the ability to appreciate the short story text which reaches the high appreciation level is the performance appraisal instrument to analyze the interrelations of intrinsic element with extrinsic element. This instrument requires students to be able to relate the reality that is in the short story text to the reality that exists in the life of the community, especially the community that is narrated in the short story text that is read by the students. Based on the student's effort to connect the reality that is in the short story text with the reality that exist in the life of society they interpret the values that can be modeled and guided for their life.

Students' high appreciation analyzes the interrelationships of intrinsic elements with extrinsic elements measured by their ability indicators: (1) making the events, backgrounds, characters and characters involved, and themes with the events, backgrounds, characters and characters of life present in society; (2) to make the social value of the short story contained in the community life; (3) establishing the linkage of the cultural values shown by the short 
story figures to those used by the community in real life; (4) to make the moral values that the short story figures show to the people in real life; (5) reveals the interrelationship of the event, the setting, the character and its character, and the themes with the existing life structure in society with the appropriate language of the rules. Except for the fifth indicator, evidence of student appreciation of the high story.

\section{Authentic Assessment Tool Ability to Appreciate Short Text for Achievement of Creative Appreciation Level}

The instrument of authentic assessment of short story text for creative appreciation learning is the conversion or paraphrasing of short story text into poetry text, or drama script to train the creativity of students writing literary texts. Students 'creativity to write poetry, measured by indicators of students' ability to convert short story text into poetry, among others, the ability to convey the theme of short stories by: (1) solidifying the works in the form of lines and verses; (2) utilizing a poetic sound; (3) using a varied diction; (4) using a suitable match.

Authentic assessment tools write creative drama scripts, for example, guide and encourage students to creativity and performance. The performance of students convert short story text into a whole drama script is a picture of the story that appears in the physical form of a drama. Indicator of student's creativity assessment is ability: (1) developing dialogue; (2) developing the role of the character; (3) developing character figures; (4) and use diction and sentence to complete the creativity of writing the drama.

\section{Authentic Assessment Tool Ability to Appreciate Short Text Text for Aspects of Language Training in Curriculum 2013}

The concept of authentic assessment for text story appreciation learning integrates also the measurement of the aspects of reading skill as a focus, accompanied by speaking, listening, writing, giving and viewing in accordance with aspects of language skills in the Curriculum 2013. The literary ability of the reading aspect is essentially reading a very important understanding for the stock of students learns many things for his life. Literally learning aims to train students to read and understand the messages in poetry or prose reading. However, for the advanced level, a deep understanding of the prose text leads students to interpret the various messages implied in the text. For this Marx, et.all (2015) argues that reading skills are an essential prerequisite for lifelong learning and participate in almost every aspect of community life.

Based on KD reading the understanding of short stories text Curriculum 2013 can be developed six authentic assessment instruments that trained 6 language skills, namely: (1) open response question instrument based on short story text, (2) instrument retell the contents of the story; (3) the instrument of performance appraisal of the beautiful text of the short story, (4) the instrument of performance appraisal compiles the synopsis and identifies the intrinsic element and analyzes the interrelations of intrinsic and extrinsic elements, (5) the instrument of product assessment writing poetry based on the short story text; (6) an oral performance appraisal instrument presents written performance outcomes, (7) an assessment instrument of interviews and conferences for the attainment of the capability of viewing a written short story text.

The authentic assessment of the ability to appreciate the short story text that contributes to the training of speech skills is the instrument of retelling the contents of the story. The assessment instrument retells the content of the story, measuring the skills of the students, telling the story they read in front of the class, in front of their friends and teachers. With an assessment instrument retelling the story content measured students' speaking skills: (1) telling the story clearly; (2) the contents of the story are told in accordance with the story he had read in advance; (3) the complete story content is measured by the original story; and (4) the content of the story is conveyed by using good and correct language rules.

Authentic assessment of learning to appreciate the short story text for reading skill is an instrument of performance assessment of beautiful text of short stories, and the instrument of performance appraisal compiles a synopsis and identifies intrinsic elements and analyzes the interrelations of intrinsic and extrinsic elements of the short story. Instrument of performance appraisal of beautiful reading of short story text measure student's ability: (1) display (physical expression) reading or voicing, (2) vowel read or vocal text of short story, and (3) appreciation.

The performance appraisal instrument compiles synopsis and identifies intrinsic elements and analyzes the interrelationships of intrinsic and extrinsic elements of the short story is a measuring tool for assessing students' ability to understand the contents of short stories that are formally read, but integrated in writing writing skills. Assessment indicators of performance appraisal instruments comprise synopsis and identify intrinsic elements that produce written reports are: (1) synoptic precision and identification of plot, background, actors / characters, and written themes; (2) completeness of synopsis and identification of plot, background, actor / character, and written theme written by the original story; (3) the synoptic compatibility and identification of plot, background, actor / character, and written theme are measured by the original story; and (4) the effectiveness or appropriateness of language use in accordance with good and correct language rules.

The performance appraisal indicator analyzes the interrelationships of intrinsic and extrinsic elements of the short story which also produce written reports are: (1) the interrelationship of intrinsic structure with extrinsic structure; 
(2) the interrelationships of social values that exist in the short story with the social values that exist in real life; (3) the linkage of cultural values that exist in the short story with the cultural values that exist in life; (4) the linkage of moral values in the short story to the moral values prevailing in life; and (5) the effectiveness of the use of language in writing reports of the intrinsic and extrinsic elements.

Authentic assessment can also be structured to measure a student's ability to communicate a student's performance product in the form of discussion or speaking skills. The instrument indicators include: (1) giving clear, concise, and concise opinions; (2) listen intently to what a friend is saying; (3) respect the opinions of friends who respond; (4) use appropriate and effective language.

For the aspect of the audience carried out learning by interview method. The type of authentic assessment used is the interviews and the use of indicators: (1) the ability to arrange text, the ability of students in choosing the topic, finding information and managing the time of data collection and writing short story text; (2) relevance, ie conformity with the theory of the prepared text; (3) the authenticity of the work (short story text) of the students by considering the contribution of teachers in the form of guidance and support.

\section{Authentic Assessment Tool for Student Character Formation}

A focused type of authentic assessment for measuring student character is the assessment of self-observation and self-assessment and peers. Assessment of observations made by the teacher throughout the learning takes place. The objectives are 2, namely: (1) to observe the involvement of students in the learning process, (2) to assess the character and social skills of students (affection). Instruments to assess student involvement in the learning process were measured by indicators: (1) readiness of students to follow the learning process; (2) sincerity of students follow the learning process; (3) students' creativity follows the learning process; (4) the ability to ask questions and answer questions; (5) the ability to take initiative; (6) the weight of ideas put forward by students in following the learning process.

Indicators established to assess the characters (items 1-10) and students' social skills (11-15) are: (1) Engaging actively in discussions; (2) to express opinions clearly and logically; (3) listening and responding to friends' opinions; (4) appreciate friends' opinions; (5) self-discipline maintains good behavior; (6) self-discipline obedient rules; (7) selfdiscipline habits waiting for the turn of speech; (8) responsible for completing joint tasks; (9) responsible for carrying out tasks as directed; (10) are responsible for working together well; (11) listen to the information well; (12) ask questions and contribute ideas in good and proper language; (13) Likes to help friends who do not understand; (14) Helping friends who have difficulty; (15) Laugh and smile at the right situation. For self-assessment and peers, the assessment indicator is the same as the teacher's observation assessment indicator.

\section{CONCLUSION AND RECOMMENDATION}

A frequently simplified assessment of its designation by assessment is one of the most important activities in education and learning today because well-planned, organized, and executed judgments greatly determine the success rate of achieving the curriculum goals. The objectives of the study of the appreciation of the prose text of the short story are addressed based on: (1) the achievement of the appreciation level includes low, medium, high, and creative appreciation; (2) training aspects of language learning according to the Curriculum 2013, including listening, speaking, reading, writing, presenting, and audiences; and (3) character building and social skills of students.

The types of ratings considered appropriate for KD to appreciate the short story text are: (1) assessment of open response questions for listening aspects; (2) retelling the contents of the short story text for the speaking aspect; (3) the performance of a beautiful reading of short stories for reading aspects; (4) the performance of intrinsic and extrinsic analyzes of writing products for aspects of comprehension reading; (5) the performance of converting or paraphrasing short story text into poetry or drama text for writing aspect; (6) the performance of comparing and evaluating short story text with other texts for the gift aspect; (7) assessment of interviews and conferences for aspects of the audiences; (8) assessment of self-assessment and self-assessment and the peer to measure the character and social skills of students.

\section{References}

Alharbi, MA. (2015). "Reading Strategies, Learning Styles and Reading Comprehension: A Correlation Study". Journal of Language Teaching and Research, 6 (6), pp. 1257-1268, November 2015. Downloaded, January 12, 2017.

Atmazaki. (2013). Alternative assessment in indonesian language learning. Padang: UNP Press.

Damono, SD. (2007). "Literature at School". Literature 5. Journal of Literature and Culture 3(5). Jakarta: The Torch Foundation.

Gitomer, DH. (2009). Measurement Issues and Assessment for Teaching Quality. Los Angeles: Sage Publications, Inc. Hasanuddin WS. (2002). Reading and assessing rhymes: Introduction to assessment and interpretation. Bandung: Space. 
Jeanings, et.al. (2006). Reading Problems: Assesment and Teaching Strategies. Boston: Pearson Education, Inc. Johnson \& Johnson. (2002). Meaningfull Assesment. Boston: Allyn and Bacon.

Kunandar. (2011). Professional teachers: Implementation of education unit level curriculum (sbc) and success in teacher certification. Jakarta: Raja Grafindo Persada.

Mahayana, MS. (2009). "Appreciation of Indonesian Literature in Schools" Susastra 5, Journal of Literature and Culture 3 (5). Jakarta: The Torch Foundation.

Mahmoud, A. (2013). "Learner Involvement in Language Development: From Course Design to Performance Assessment”. Journal of Language Teaching and Research, 4 (4), pp. 679-683, July 2013. Downloaded, January 12, 2017.

Mahsun. (2014). Text in learning indonesian curriculum 2013. Jakarta: PT Raja Grafindo Persada.

McMillan, JH. (2007). Formative classroom assesment. Columbia: Teachers College Press.

Nitko, AJ. (2001). Educational assesment of students. New Jersey: Upper

Sarumpaet, RKT. (2007). "With Literature Being Human". Susastra 5, Journal of Literature and Culture 3(5). Jakarta: The Torch Foundation.

Santosa, P. (2003). "Literature Learning in Elementary School". UT Module. Jakarta: Open University.

Sukardi. (2009). Evaluasi pendidikan: Prinsip dan operasionalnya. Jakarta: Bumi Aksara.

Sugito, E. (2009). "Assessment of Linguistic Skills in Elementary School". UT Module. Jakarta: Open University.

Soegiyono. (2009). Educational Research Methods Quantitative Approach, Qualitative and R \& D. Bandung: Alfabeta.

Trianto. (2007). Innovative Learning Models are Constructivist-oriented. Jakarta: Publisher Publisher Achievement.

Trianto. (2012). Integrated Learning Model: Concepts, Strategies, and Implementation in Education Unit Level Curriculum. Jakarta: Earth Literacy.

Wahyudi, I. (2007). "Tackling the Curriculum and Lessons of Indonesian Literature in School: Tips for Mafhum and Cleaning". Susastra 5, Journal of Literature and Culture 3 (5). Jakarta: The Torch Foundation. 